DOI: $\underline{\text { https://doi.org/10.31933/jemsi.v2i5 }}$

Received: 16 April 2021, Revised: 15 Mei 2021, Publish: 25 Juni 2021

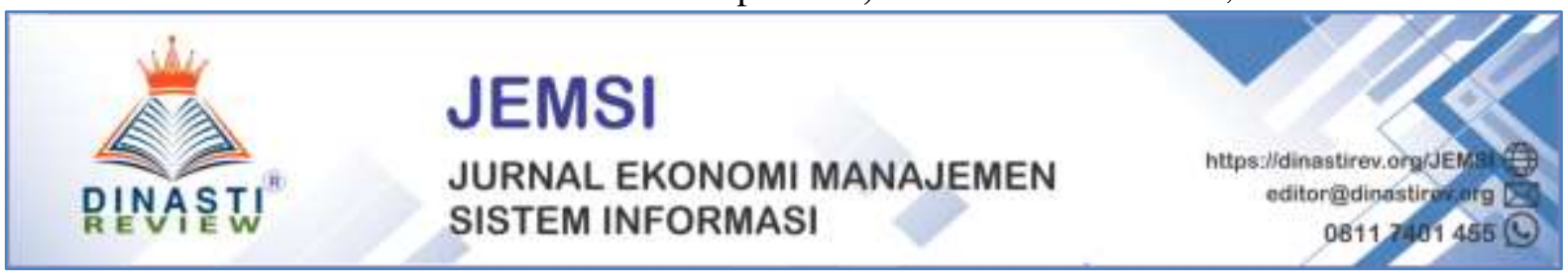

\title{
ASPEK TEKNIS, ASPEK FINANSIAL DAN ASPEK SENSITIVITASNYA TERHADAP PERUBAHAN FEED CONVERSION RATIO (FCR) DAN ANALISIS STRENGTHS, WEAKNESSES, OPPORTUNITIES AND THREATS (SWOT)
}

\author{
Sri Wahyuni Lestari ${ }^{1)}$ \\ 1) Fakultas Program Manajemen Sumber Daya Manusia (SDM), Universitas Mercu Buana \\ email: sri321977@gmail.com
}

\begin{abstract}
Abstrak: Komoditas unggas mempunyai prospek pasar yang sangat baik, karena didukung oleh karakteristik produk unggas yang mudah diterima oleh masyarakat Indonesia. Jumlah penduduk Indonesia mencapai 207,2 juta jiwa dan masih tumbuh 1,4\% per tahun yang merupakan sebuah pasar yang sangat potensial sebagai konsumen produk usaha ternak unggas. Tujuan penelitian ini ialah untuk: (a) mengidentifikasi sistem manajemen usaha peternakan ayam pedaging melalui pola kemitraan dengan PT Sreeya Sewu Indonesia, (b) menganalisis kelayakan usaha peternakan ayam pedaging melalui pola kemitraan PT Sreeya Sewu Indonesia dilihat dari aspek teknis, aspek finansial dan aspek sensitivitasnya terhadap perubahan feed conversion ratio (FCR) dan (c) menyusun strategi pola kemitraan yang dilakukan peternak. Pengumpulan data dilakukan dengan cara pengamatan langsung terhadap empat usaha peternakan ayam pedaging melalui wawancara dengan pemilik peternakan. Data yang diperoleh berupa data primer dan sekunder digunakan untuk mengidentifikasi sistem manajemen usaha peternakan ayam pedaging dan analisis Strengths, Weaknesses, Opportunities and Threats (SWOT) untuk mengetahui strategi yang perlu dikembangkan secara umum. Peternakan ayam pedaging yang baik dengan menggunakan kandang panggung yang terbuat dari bahan permanen beratap genteng. Dengan melaksanakan sistem manajemen pemeliharaan yang baik pada periode starter, pertumbuhan dan panen. Hasil analisis kelayakan usaha dari aspek finansial dengan skala pemeliharaan 22.000 ekor, 14.000 ekor, 8.000 ekor, dan 4.000 ekor dengan tingkat suku bunga 16\%, menunjukkan usaha peternakan layak untuk dilaksanakan dan dikembangkan. Alternatif strategi dari hasil analisis SWOT adalah meningkatkan produktivitas untuk meningkatkan keuntungan, efisiensi dan produktifitas untuk menanggulangi permasalahan teknis yang terjadi.
\end{abstract}

Kata Kunci: Aspek teknis, Aspek finansial dan Aspek sensitivitasnya terhadap perubahan feed conversion ratio (FCR) dan Analisis Strengths, Weaknesses, Opportunities and Threats (SWOT).

\section{PENDAHULUAN}

\section{Latar Belakang Masalah.}

Agribisnis peternakan merupakan segala aktivitas bisnis yang terkait dengan kegiatan budi daya ternak, industri hulu, industri hilir, dan lembaga-lembaga pendukung. Agribisnis tersebut merupakan salah satu bidang yang sangat penting bagi hajat hidup masyarakat dan memiliki potensi dijadikan sebagai penggerak utama ekonomi nasional. Usaha peternakan 
bahkan mampu meningkatkan ekonomi pedesaan dan sekaligus meningkatkan pendapatan masyarakat.

Pengembangan struktur industri peternakan yang masih tersekat-sekat dan belum menunjukkan keterkaitan yang kuat antara satu dan lain subsistem agribisnis peternakan. Agribisnis ayam pedaging juga merupakan bisnis yang penuh gejolak dan berisiko, hampir setiap tahun dijumpai gejolak harga dengan intensitas yang berbeda dan selalu menempatkan peternak dalam posisi rawan. Siklus gejolak biasanya diawali dengan naiknya harga sarana produksi peternakan dan sering diikuti dengan turunnya harga jual produk. Naiknya sarana produksi menyebabkan peningkatan biaya produksi, tetapi menurunkan pendapatan peternak sampai di bawah ambang batas titik impas. Turunnya pendapatan yang berkepanjangan menyebabkan peternak menghentikan usahanya. Hal ini mengakibatkan permintaan DOC (day old chicken) berkurang dan menyebabkan supply produk (daging ayam) menurun, sehingga penawaran lebih rendah dari permintaan. Gejolak terbesar sepanjang sejarah agribisnis ayam pedaging terjadi sejak Juli 1997 berupa krisis moneter yang diikuti krisis ekonomi. Khususnya peternakan rakyat salah satu cara untuk menanggulangi permasalahan tersebut dengan menerapkan pola kemitraan yamg memperhatikan prinsip saling memerlukan, saling memperkuat dan saling menguntungkan (Blessing, 2007). Tujuan kajian ini adalah mengidentifikasi sistem manajemen usaha peternakan ayam pedaging melalui pola kemitraan.

\section{Rumusan Masalah.}

Adanya latar belakang seperti diuraikan di atas maka dapat ditentukan beberapa rumusan masalah sebagai berikut.

1. Bagaimanakah profil peternak ayam pedaging dibawah kemitraan PT Sreeya Sewu Indonesia?

2. Apakah yang menjadi faktor-faktor kekuatan, kelemahan, peluang, dan ancaman pengembangan agribisnis peternakan ayam pedaging dibawah kemitraan PT Sreeya Sewu Indonesia?

3. Alternatif strategi apakah yang dapat dirumuskan untuk pengembangan agribisnis peternakan ayam pedaging dibawah kemitraan PT Sreeya Sewu Indonesia?

Prioritas strategi apa yang seharusnya dipilih dalam rangka pengembangan peternakan ayam pedaging dibawah kemitraan PT Sreeya Sewu Indonesia?

\section{Kajian Teori}

Kajian ini dilakukan pada peternak plasma yang bermitra dengan PT Sreeya Sewu Indonesia yang berlokasi di Parung, Kabupaten Bogor. Pemilihan lokasi ini didasarkan pada 
pertimbangan sebagai daerah kawasan peternakan ayam pedaging yang sebagian besar usahanya dilaksanakan dengan pola kemitraan dalam skala pemeliharaan ayam beragam. Jumlah peternak plasma yang bermitra dengan PT Sreeya Sewu Indonesia di lokasi tersebut sebanyak delapan peternak, dengan skala pemeliharaan 4.000 ekor, 5.000 ekor, 8.000 ekor, 10.000 ekor, 12.000 ekor, 14.000 ekor, 18.000 ekor, dan 22.000 ekor.

Dalam kajian ini digunakan data primer dan sekunder. Data primer diperoleh dengan melakukan pengamatan di lapangan, wawancara, dan pengisian kuesioner oleh peternak plasma. Data yang diperoleh digunakan untuk mengetahui tujuan dan strategi peternak plasma sebelumnya, serta melakukan audit eksternal dan internal yang merupakan dasar bagi analisis perumusan strategi selanjutnya. Selain itu, digunakan analisis teknis untuk mengidentifikasi faktor-faktor teknis yang berpengaruh pada pemeliharaan ayam, yang meliputi manajemen pemeliharaan periode starter, periode pertumbuhan dan periode panen; Analisis lingkungan; Analisis biaya untuk mengetahui jumlah biaya yang dikeluarkan oleh peternak plasma; dan Analisis keuangan untuk mengetahui kelayakan usaha, dilakukan dengan metode discounted cash flow, meliputi Net Present Value (NPV), Internal Rate of Return (IRR) dan Net Benefit/Cost Ratio (Net B/C). Untuk menyusun strategi pengembangan usaha peternakan ayam pedaging, digunakan matriks SWOT.

Menurut Rangkuti (2008), penentuan strategi utama dengan tiga tahapan dan kerangka kerja sebagai model analisisnya dengan matriks. Matriks tersebut dapat dipakai untuk membantu para ahli strategi dalam mengidentifikasi, mengevaluasi, dan memilih strategistrategi yang paling tepat. Ada beberapa tahapan yang diperlukan antara lain, yaitu:

\section{Input Stage}

Berfungsi untuk menyampaikan informasi dasar yang diperlukan untuk merumuskan strategi. Perumusan strategi yang digunakan dalam penelitian terdiri dari dua macam matriks, yaitu:

a. IFE (Internal factor evaluation) digunakan untuk faktor-faktor internal pengembangan peternakan ayam pedaging yang berkaitan dengan kekuatan dan kelemahan.

b. Matriks EFE (External factor evaluation) yang digunakan untuk mengevaluasi faktorfaktor eksternal pengembangan peternakan ayam pedaging, mengenai peluang dan ancaman.

\section{Matching Stage}

Berfungsi untuk pengambilan strategi alternatif yang fleksibel dilakukan melalui pengembangan faktor internal dan eksternal yang utama untuk memilih atau merumuskan strategi mana yang terbaik, maka matriks yang digunakan sebagai matching stage adalah 
diagram dan matriks SWOT (Strengths, Weaknesses, Opportunities, and Threats). Setelah diagram analisis SWOT terbentuk, kemudian dibuat matriks SWOT yang menjelaskan berbagai alternatif yang mungkin untuk membantu mengambil kebijakan dengan mengembangkan strategi yang operasional dengan empat tipe strategi.

\section{Decision stage}

Menggunakan analisis QSPM (Quantitative Strategics Planning Matrix) yang bertujuan untuk menetapkan ketertarikan relatif (relative attractivness) dari strategi-strategi yang bervariasi yang telah dipilih dengan total score attractivness tertinggi untuk menentukan strategi yang paling baik sebagai strategi prioritas yang diimplementasikan pada pengembangan peternakan ayam pedaging.



Gambar 1 Strategi Pengembangan Agribisnis Peternakan Ayam Pedaging

Menurut Lestari dan Triani (2013) menyatakan bahwa suatu perusahaan memerlukan strategi yang efektif untuk dapat mencapai recovery atau keberhasilan turnaround. Proses pencocokan antara elemen kekuatan, kelemahan, peluang dan ancaman dilakukan setelah analisis matriks IFE dan EFE, dengan menggunakan matriks SWOT yang dinyatakan dalam matriks QSP. Matriks Perencanaan Strategis Kuantitatif (Quantitative Strategic Planning 
MatrixQSPM) dirancang untuk menentukan daya tarik relatif dari berbagai tindakan alternatif. QSPM menggunakan analisis input pada tahap 1 (matriks IFE dan EFE) dan hasil pencocokan dari analisis tahap 2 (matriks SWOT). Teknik ini secara objektif menunjukkan strategi mana yang terbaik dari beberapa alternatif strategi yang dihasilkan.

Analisis SWOT menurut Kurniawan et al (2013) adalah metode perencanaan strategi yang digunakan untuk mengevaluasi kekuatan, kelemahan, peluang dan ancaman dalam suatu spekulasi bisnis. Berdasarkan analisis SWOT, untuk penentuan kebijakan dilakukan dengan mengembangkan empat (4) strategi, yaitu

\section{Strategi SO (Strenghts Opportunities)}

Menghasilkan strategi "Peningkatan pangsa pasar untuk meraih posisi market leader melalui kebijakan dari pemerintah daerah". Strategi ini dijalankan dengan memperbesar jumlah populasi ternak ayam ras pedaging sehingga produksi ayam pedaging meningkat, tujuannya agar dapat menguasai pasar lokal yang berdampak terhadap adanya peluang pasar.

\section{Strategi WO (Weaknesses Opportunities)}

menghasilkan strategi "Peningkatan kualitas sumber daya manusia (SDM) melalui pembinaan dan pendampingan untuk peningkatan produktivitas". Strategi ini dijalankan dengan memberikan pelatihan-pelatihan dan pembimbingan kepada peternak untuk meningkatkan keterampilan peternak dalam menjalankan usaha sehingga produktivitasnya meningkat. Peningkatan produktivitas membuat peternak dapat memenuhi permintaan pasar telur yang cukup tinggi dan meraih peluang kerjasama dengan investor

\section{Strategi ST (Strenghts Threats)}

Strategi "Penyediaan sarana produksi peternakan khususnya pakan di daerah dengan memanfaatkan bahan baku lokal yang tersedia". Strategi ini dijalankan dengan memanfaatkan sumber daya alam/potensi lokal yang ada untuk pembuatan pakan ternak guna mengurangi ketergantungan pakan dari luar daerah. Hal ini juga dapat menekan biaya produksi sehingga harga ayam pedaging bisa bersaing dari luar daerah.

\section{Strategi WT (Weaknesses Threats)}

Merupakan taktik defensif yang diarahkan untuk mengurangi kelemahan internal serta menghindari ancaman eksternal, menghasilkan strategi "Terjalinnya kerjasama melalui pola kemitraan antara peternak dan pihak swasta/perusahaan peternakan”. Strategi ini dijalankan melalui kerjasama antara peternak dengan perusahaan peternakan dalam penyediaan bibit, pakan dan sarana produksi lainnya. Kemitraan akan menguntungkan karena peternak dapat turut mengambil bagian manfaat dari pasar, modal, teknologi dan manajemen yang dikuasai perusahaan besar. 


\section{METODE PENELITIAN}

Penelitian ini dirancang untuk mengetahui mengetahui profil peternak ayam pedaging, menganalisis faktor-faktor kekuatan, kelemahan, peluang, dan ancaman pada pengembangan agribisnis peternakan ayam pedaging, merumuskan alternatif strategi pengembangan agribisnis peternakan ayam dan menentukan prioritas strategi yang harus dilakukan pengembangan agribisnis peternakan ayam pedaging.

\section{Analisis Manajemn Usaha}

Manajemen usaha peternakan ayam pedaging meliputi manajemen pemeliharaan periode starter, periode pertumbuhan, dan periode panen. Hal-hal yang harus dipersiapkan untuk memasuki periode starter adalah membuat perencanaan dan menghitung kebutuhan sarana produksi, serta mempersiapkan kandang. Untuk periode selanjutnya, yaitu periode pertumbuhan, dilakukan pengaturan luas lantai kandang dan kepadatan ayam, persiapan peralatan kandang, pemberian pakan yang tepat, pemberian air minum yang cukup, pengaturan keadaan litter, pengaturan penerangan, pengaturan ventilasi kandang, pengaturan temperatur kandang, pelaksanaan program pencegahan penyakit, pembuatan laporan, pengontrolan pertumbuhan, dan penanganan ayam mati dan kotoran ayam. Periode terakhir, yaitu periode panen yang dibagi atas masa sebelum panen, ketika panen dan pasca panen. Di samping itu juga ada unsur bukan teknis yang mendukung meliputi administrasi, pemasaran, keuangan, dan pengadaan (Rasyaf, 2001).

Dalam program kemitraan ini, peternak plasma tidak dapat menentukan waktu panen, karena penentuan waktu panen merupakan kewenangan perusahaan inti, sehingga analisis hanya dilakukan pada periode starter dan pertumbuhan. Untuk mengetahui perbedaan manajemen pemeliharaan yang dilaksanakan oleh keempat peternak yang dikaji, data disajikan pada Tabel 1. Tabel 1 menunjukkan adanya persamaan bentuk kandang, sistem brooder, dan tempat pakan yang digunakan oleh keempat peternak. Pada periode starter peternak menggunakan kandang berbentuk panggung dan sistem brooder dengan alat pemanas gasolek dan pada periode pertumbuhan peternak menggunakan tempat pakan jenis feeder tube. Peternakan milik Peternak 1 dan Peternak 2 menggunakan kandang yang berbentuk panggung setinggi 4 m dengan bahan kayu, pondasi batu bata, dan atap kandang sistem monitor. Namun terdapat perbedaan pada bahan atapnya, yaitu kandang milik Peternak 1 menggunakan genteng dan Peternak 2 menggunakan asbes.

Sedangkan peternakan milik Peternak 3 menggunakan kandang berbentuk panggung setinggi $3 \mathrm{~m}$, dengan bahan kayu dan bambu serta dinding tertutup tirai (kandang tertutup). Pondasi kandang terbuat dari kayu dan atap kandang terbuat dari seng dan tidak menggunakan 
sistem monitor, sehingga ventilasi udara sangat mengandalkan kinerja blower, jika blower tidak bekerja dengan baik, suhu kandang akan cepat naik akibat dari bahan atap yang terbuat dari seng. Selain itu, tinggi kandang terlalu rendah, karena tinggi ideal yaitu 3,5-4 m. Lokasi kandang terletak di tengah hutan pinus dan berjarak kurang lebih $500 \mathrm{~m}$ dari pemukiman penduduk. Lokasi ini cukup baik, karena jauh dari keramaian dan tidak menimbulkan polusi bau bagi penduduk, namun kurang mendapatkan pertukaran udara yang baik, karena terhalang oleh pohon-pohon pinus. Kandang ideal berada pada dataran luas tanpa penghalang.

Sistem brooder menggunakan alat pemanas gasolek dengan kepadatan 1.000 ekor per brooder dan disekat dengan seng. Pemakaian gasolek memiliki kelebihan, yaitu panas yang dihasilkan relatif merata, stabil dan tidak terpengaruh angin, namun kapasitas brooder tersebut terlalu padat (idealnya 750-800 ekor). Hal ini akan menyebabkan panas yang ditimbulkan oleh brooder tidak dapat diterima secara merata oleh ayam. Jumlah ayam yang dipelihara oleh peternak 3 ialah 8.000 ekor dengan kepadatan 4.000 ekor per kandang, atau 11-12 ekor per m2. Kondisi tersebut cukup padat dan dapat menghambat pertumbuhan ayam.

Peternakan milik Peternak 4 menggunakan kandang berbentuk panggung setinggi $3 \mathrm{~m}$, dengan bahan bambu dan tidak seluruh dinding tertutup (setengah tirai). Pondasi kandang terbuat dari kayu dan atap terbuat dari rumbia. Jika dilihat dari bentuk dan bahannya, kandang ini kurang permanen. Penggunaan rumbia sebagai bahan atap cukup baik untuk meredam udara luar yang panas, namun kurang tahan lama dan sering mengalami kebocoran pada saat hujan. Lokasi kandang berada dekat dengan perumahan dengan jarak kurang lebih $50 \mathrm{~m}$ dari kandang. Lokasi kandang yang baik harus jauh dari pemukiman penduduk, dengan tujuan untuk menghindari konflik dengan lingkungan akibat polusi bau, atau polusi debu, serta ayam terhindar dari kontaminasi penyakit yang dibawa manusia atau binatang lainnya, seperti ayam kampung/buras, itik, anjing, kambing, sapi, dan kerbau.

Sistem brooder menggunakan alat pemanas gasolek dengan kepadatan 1.000 ekor per brooder dan disekat dengan kayu. Seperti kandang milik peternak 3, kapasitas brooder terlalu padat, ditambah lagi dengan penyekatnya menggunakan kayu, karena kayu merupakan penghantar panas yang buruk sehingga kurang menghangatkan bagian yang disekatnya.

Jumlah ayam yang dipelihara oleh peternakan milik peternak 3 ialah 4.000 ekor, dengan menggunakan satu kandang yang kepadatannya 16-17 ekor per m2. Kondisi tersebut sangat padat dan sangat menghambat pertumbuhan ayam.

Perbedaan pelaksanaan manajemen pemeliharaan pada keempat peternak plasma ditimbulkan oleh besarnya skala pemeliharaan yang dilaksanakan dan modal yang dimiliki peternak. Semakin besar skala pemeliharaan akan semakin banyak pula modal yang diperlukan, 
karena untuk menghindari risiko kerugian akibat tingkat kematian ayam yang tinggi, maka peternak harus melaksanakan manajemen pemeliharaan sesuai standar yang memerlukan biaya banyak.

Tabel 1. Sistem manajemen pemeliharaan ayam pedaging pada masing-masing peternak

\begin{tabular}{|c|c|c|c|c|}
\hline \multirow{2}{*}{ Uraian } & \multicolumn{4}{|c|}{ Nama Peternak } \\
\hline & Peternak 1 & Peternak 2 & Peternak 3 & Peternak 4 \\
\hline \multicolumn{5}{|l|}{ Periode Starter } \\
\hline Tahun berdiri & 2003 & 2001 & 2006 & 2001 \\
\hline Bentuk kandang & Panggung & Panggung & Panggung & Panggung \\
\hline Bahan kandang & Kayu & Kayu & Kayu + Bambu & Bambu \\
\hline Pondasi kandang & Batu bata & batu bata & Kayu & Kayu \\
\hline Tirai kandang & Penuh & Penuh & Penuh & setengah \\
\hline Sistem atap kandang & Monitor & Monitor & tanpa monitor & tanpa monitor \\
\hline Bahan atap kandang & Genteng & Asbes & Seng & Rumbia \\
\hline Tinggi kandang (m) & 4 & 4 & 3 & 3 \\
\hline Lebar kandang (m) & 7 & 6 & 6 & 6 \\
\hline Panjang kandang (m) & 65 & 45 & 60 & 40 \\
\hline Jarak kandang dengan perumahan (m) & 100 & 50 & 500 & 50 \\
\hline Lokasi kandang & di atas bukit & di tengah sawah & di tengah hutan pinus & dekat perumahan \\
\hline Jarak antarkandang (m) & 5 & 3 & 2 & - \\
\hline Sistem brooder & Gasolek & Gasolek & Gasolek & Gasolek \\
\hline kepadatan brooder (ekor/rooder) & 800 & 800 & 1000 & 1000 \\
\hline Sekat brooder & Seng & Seng & Seng & Kayu \\
\hline \multicolumn{5}{|l|}{ Periode Pertumbuhan } \\
\hline Sistem alas kandang & full sekam & setengan seкam & setengan sekam & setengan seкаm \\
\hline Jumlah populasi total & 22000 & 14000 & 8000 & 4000 \\
\hline Tempat pakan & Feeder tube & Feeder tube & Feeder tube & Feeder tube \\
\hline Tempat minum & automatic drinker & Manual & Manual & Manual \\
\hline
\end{tabular}

\section{Analisis Kelayakan Usaha Teknis}

Analisis teknis dilakukan untuk menilai pelaksanaan manajemen usaha peternakan ayam pedaging yang meliputi manajemen pemeliharaan periode starter, periode pertumbuhan, dan periode panen. Pertumbuhan ayam akan terganggu, bila manajemen pemeliharaan pada periode tersebut tidak dilaksanakan sesuai dengan standar, yang pada akhirnya bobot badan yang dihasilkan tidak optimal dan feed conversion rate (FCR) akan lebih tinggi daripada standar umur panen pada bobot 1,55 yang dicapai pada kisaran pemeliharaan hari ke 32, atau 33. Hasil pengamatan di lapangan menunjukkan keempat peternak kurang melaksanakan manajemen brooding yang baik, seperti lama pemanasan dan kepadatan per brooder, sehingga pertumbuhan awal minggu yang menjadi kunci sukses pemeliharaan ayam sering kali tidak tercapai, yang pada akhirnya berdampak kurang baik bagi pendapatan peternak. 
Namun berdasarkan pengamatan di lapangan, keempat peternak biasanya menyalakan pemanas hanya beberapa jam sebelum DOC masuk, bahkan ada peternak yang menyalakan pemanas bersamaan dengan penempatan DOC ke dalam lingkaran. Hal ini akan menyebabkan lingkaran tidak langsung hangat sehingga DOC memerlukan waktu lebih lama untuk beradaptasi. Pemanasan sebaiknya dilakukan hingga anak ayam berumur 18-21 hari kepadatan yang ideal kendang adalah 750-800 ekor. Hal ini dilakukan untuk menekan biaya pemanas akibat tingginya harga bahan bakar gas. Pendapat ini tidak sepenuhnya benar, karena jika pemanasan kurang akan mengganggu pertumbuhan ayam. Bobot badan ayam akan menjadi tidak rata dan proses pembentukan kekebalan tubuhnya terganggu, akibatnya ayam banyak yang kerdil dan mudah terserang penyakit.

Penyakit yang sering menyerang ayam pada periode pertumbuhan adalah gumboro, CRD, newcastle disease (ND), coccisiosis, bakteri Escherichia coli dan jamur. Penyebab timbulnya penyakit pada ayam yaitu, mutu DOC jelek, sehingga ketahan tubuhnya lemah, kegagalan sanitasi ketika mempersiapkan kandang, kegagalan vaksinasi, terinfeksi penyakit, dan faktor lain, seperti stres. Aspek nonpenyakit dapat terjadi antara lain karena terinjak pekerja, penumpukan DOC akibat kedinginan, atau stres yang berlebihan dan dimakan oleh binatang pemangsa. Di antara keempat peternakan yang dikaji, peternakan milik peternak 4 adalah yang paling rentan terhadap terjadinya deplesi. Atap kandang milik Munir yang terbuat dari rumbia dan sistem kandang setengah tertutup akan menyebabkan ternak terancam kedinginan. Selain itu populasi ayam sebanyak 16-17 ekor per $\mathrm{m} 2$ tergolong terlalu padat, sehingga membuat ayam stres.

Pada periode panen sering terjadi permasalahan pada penentuan jadwal panen. Keempat peternak plasma mengeluhkan sering terjadi keterlambatan panen yang dilakukan oleh inti. Keterlambatan panen mengakibatkan kerugian bagi peternak, karena pertumbuhan ayam akan mencapai puncak pada umur 32-33 hari, sedangkan biaya operasional harus tetap dikeluarkan untuk mempertahankan bobot badan yang telah dicapai. Sebaliknya pada saat harga pasar naik perusahaan inti memaksa memanen ayam sebelum waktunya. Percepatan panen merugikan peternak, karena ayam belum mencapai bobot yang optimal 
Tabel 2. Lama pemanasan dan kepadatan per brooder

\begin{tabular}{cccc}
\hline No & \multicolumn{1}{c}{$\begin{array}{c}\text { Nama Peternak/ } \\
\text { Skala Pemeliharaan (ekor) }\end{array}$} & $\begin{array}{c}\text { Lama Pemanasan } \\
\text { (hari) }\end{array}$ & $\begin{array}{c}\text { Kepadatan Brooder } \\
\text { (ekor/ brooder) }\end{array}$ \\
\hline 1 & Peternak 1 / 22.000 & 10 & 800 \\
2 & Peternak 2 / 14.000 & 10 & 800 \\
3 & Peternak 3 / 8.000 & 10 & 1000 \\
4 & Peternak 4 / 4.000 & 10 & 1000 \\
\hline
\end{tabular}

\section{Aspek Keuangan}

Analisis finansial dilakukan untuk mengetahui jumlah modal, jenis-jenis penggunaannya dalam pendirian dan pelaksanaan usaha peternakan ayam pedaging dengan mengidentifikasi aliran kas yang ada. Aliran kas (cashflow) dihitung berdasarkan perkiraan pemasukan (inflow) dan pengeluaran (outflow) yang terjadi sebagai konsekuensi dari pengadaan, serta operasi suatu usaha dalam kurun waktu tertentu. Inflow dalam usaha peternakan ayam pedaging berasal dari penjualan ayam panen, pupuk kandang, karung pakan, dan insentif selisih FCR, sedangkan outflow berasal dari biaya investasi dan biaya operasional. Inflow merupakan penerimaan yang berhasil diterima oleh peternak plasma setelah ayam dipanen pada setiap periode produksi. Dalam kajian ini penerimaan dari penjualan ayam panen dihitung dengan asumsi kematian/deplesi ayam pada masa pemeliharaan 4\%, bobot ayam 1,55 kg/ekor dan harga garansi Rp 12.070/kg. Penerimaan dari penjualan pupuk kandang diperoleh dengan asumsi bahwa setiap $1 \mathrm{~m} 2$ kandang menghasilkan setengah karung pupuk kandang dengan harga jual Rp 3.000/karung. Penerimaan dari insentif FCR diperoleh jika peternak berhasil mencapai FCR di bawah FCR standar (1,65). Penerimaan dari karung pakan diperoleh dari penjualan dengan harga Rp 1.500,00/karung. Tabel 3 menunjukkan jumlah penerimaan yang dapat diterima oleh peternak plasma dari empat skala pemeliharaan pada setiap periode produksi.

Tabel 3. Jumlah penerimaan per periode produksi Skala Jumlah Penerimaan Berdasarkan

\begin{tabular}{|c|c|c|c|c|}
\hline \multirow[t]{2}{*}{ No } & \multirow{2}{*}{$\begin{array}{c}\text { Skala } \\
\text { Pemeliharaan }\end{array}$} & \multicolumn{3}{|c|}{$\begin{array}{c}\text { Jumlah Penerimaan Berdasarkan } \\
\text { Nilai FCR (Rp) haraan }\end{array}$} \\
\hline & & 1,5 & 1,6 & 1,7 \\
\hline 1 & 22.000 & 405.412 .800 & 403.121 .280 & 399.520 .320 \\
\hline 2 & 14.000 & 258.033 .600 & 256.575 .360 & 254.283 .840 \\
\hline 3 & 8.000 & 147.379 .200 & 146.545 .920 & 145.236 .480 \\
\hline 4 & 4.000 & 73.569 .600 & 73.152 .960 & 72.498 .240 \\
\hline
\end{tabular}




\section{KESIMPULAN DAN SARAN}

\section{Kesimpulan}

1. Hasil analisis manajemen usaha peternakan ayam pedaging, yaitu Peternak 1 dengan skala pemeliharaan 22.000 ekor dengan kandang permanen memenuhi standar dan kepadatan populasi per kandang sudah cukup baik, yaitu 8-9 ekor per m2; Peternak 2 dengan skala pemeliharaan 14.000 ekor dengan kandang permanen berbahan atap asbes, kurang baik dalam meredam panas, kandang terlalu padat (13 ekor per m2); Peternak 3 dengan skala pemeliharaan 8.000 ekor dan Peternak 4 dengan skala pemeliharaan 4.000 ekor masih menggunakan kandang tidak standar (tinggi kandang $3 \mathrm{~m}$, atau $<3,5-4 \mathrm{~m}$ ), kepadatan kandang milik Furqon terlalu padat (11-12 ekor per m2) dan Munir 16 - 17 ekor per m2.

2. Hasil analisis kelayakan usaha dari aspek teknis, yaitu keempat peternak kurang melaksanakan manajemen pemeliharaan ayam sesuai standar, khususnya pada periode starter/brooding. Keempat peternak terbiasa menyalakan pemanas hanya beberapa jam sebelum DOC masuk, yang seharusnya pemanas dinyalakan satu hari sebelum DOC datang. Pemanasan hanya dilakukan selama 10 hari, atau kurang dari standar lama pemanasan, yaitu 18-21 hari. Kepadatan per brooder pada peternakan milik Peternak 3 dan Peternak 4 terlalu padat, yaitu 1.000 ekor per brooder, yang seharusnya 750-850 ekor per brooder. Analisis kelayakan finansial terhadap usaha peternakan ayam pedaging dengan pola kemitraan, dengan tingkat suku bunga 16\%, dapat dikatakan layak dan dikembangkan, jika dapat mencapai nilai FCR 1,5. Dalam hal ini, nilai FCR yang semakin naik akan menurunkan keuntungan peternak, bahkan peternak akan merugi, jika nilai FCR lebih besar dari nilai FCR standar $(1,65)$.

3. Alternatif strategi dari hasil analisis SWOT adalah meningkatkan produktivitas untuk meningkatkan keuntungan, meningkatkan efisiensi penggunaan sapronak, bersikap proaktif untuk menanggulangi permasalahan teknis yang terjadi, meningkatkan pengetahuan tentang penanganan penyakit, mengoptimalkan pemanfaatan sapronak, meningkatkan manajemen pemeliharaan sesuai standar, dan meningkatkan pengetahuan peternak mengenai manajemen pemeliharaan ayam yang baik.

\section{Saran}

1. Pemerintah diharapkan turut serta dalam pengembangan saha peternakan ayam pedaging untuk mendukung peternak dalam meningkatkan pangsa pasar, agar penjualan peternak menjadi meningkat dan pangsa pasar tidak didahului oleh kompetitor yang berasal dari luar negri. 
2. Mengoptimalkan penyuluhan kepada peternak ayam pedaging agar terhindar dari berbagai ancaman yang dapat sewaktu-waktu terjadi.

3. Peternak diharapkan mencari solusi yang tepat guna untuk pendanaan dalam usaha peternakan ayam, agar sewaktu-waktu dapat memenuhi kebutuhan usaha. Selain itu, peternak juga harus lebih selektif dalam memilih lembaga keuangan dan jenis kredit yang ada, agar pendanaan tersebut dapat sesuai kebutuhan usaha.

\section{DAFTAR PUSTAKA}

Mietha. 2008. Manfaat Telur. Internet http://mietha.wordpress.com/2008/telur Diunduh Januari 2013.

Rangkuti, Freddy. 2008. Analisis SWOT Teknis Membedah Kasus Bisnis. Jakarta: Gramedia Pustaka Utama.

Blessing. 2007. Himpunan Undang-undang dan Peraturan tentang Waralaba Direct Selling. Blessing, Jakarta.

Sutawi. 2007. Agribisnis Peternakan. Kapita selekta. Universitas Muhamadiyah Malang Press, Malang.

Antara, Made. 2006. Metodologi Penelitian Agribisnis. Denpasar: Magister Manajemen Agrbisnis Udayana Bali.

Fadilah R. 2005. Panduan Mengelola Peternakan Ayam Broiler Komersial. Agromedia Pustaka, Jakarta.

Rangkuti F. 2003. Analisis SWOT: Teknik Membedah Kasus Bisnis. Gramedia Pustaka Utama, Jakarta.

Umar, Husein. 2002. Strategic Management In Action. Jakarta: PT Gramedia Pustaka.

Rasyaf, M. 2001. Beternak Ayam Pedaging. Penebar Swadaya, Jakarta.

Soeharno. 2000. Kiat Sukses Berbisnis Ayam. Jakarta: Penebar Swadaya.

Rasyaf, M, 1995. Manajemen Peternakan Ayam Petelur. Jakarta: Penebar Swadaya. 